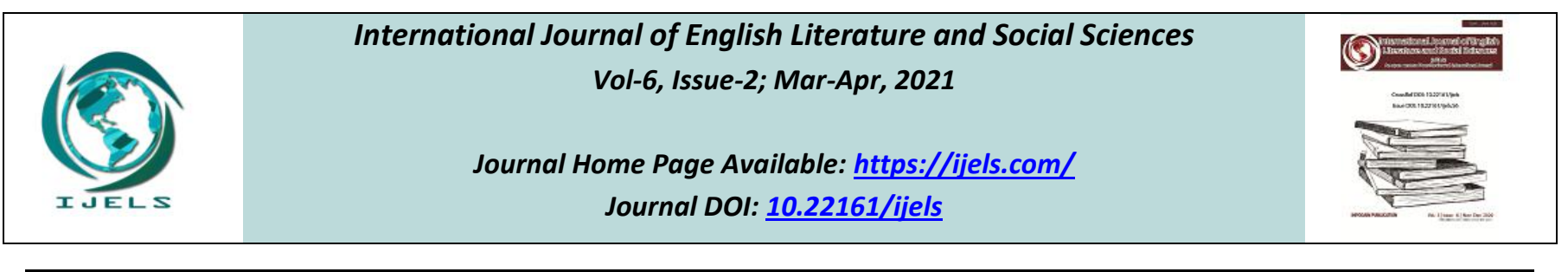

\title{
Al-A'râf:(A Wall With Elevated Places) Scene in a New Western Perspective
}

\author{
Dr. Shamim Radhi Abd
}

Received: 25 Nov 2020; Received in revised form: 29 Jan 2021; Accepted: 13 Feb 2021; Available online: 05 Mar 2021

C2021 The Author(s). Published by Infogain Publication. This is an open access article under the CC BY license

(https://creativecommons.org/licenses/by/4.0/).

\begin{abstract}
The attention of researchers has aroused the issue of the influence between Arab Islamic literature and Western literature, and among these works is the work of Dante, the well-known "Divine Comedy", which was translated into many languages due to the impact it left on the hearts of its recipients.

In this paper, we shed light on the scene of the companions of elevations (Al Araf), which the Holy Qur'an portrayed well, and this scene came in the same image for Dante, and through this scene we tried to show the extent of the influence of Islamic sciences on Western literature.

We started our research with an introduction in which we defined the walls (Al Araf) in language and idiomatically a brief about the book of the Divine Comedy, then we mentioned in the first section about norms in Noble Qur'an and in the Sunnah and among the commentators to conclude this topic with (limbos) of Dante in the Divine Comedy, while the second section came to explain the issue of influence between the sciences, The paper ended with a number of conclusions.
\end{abstract}

Keywords-Al-Araf ( The Wall), Dante, Divine Comedy, Limbo scene and Islamic influence.

\section{INTRODUCTION}

Praise be to God, Lord of the worlds, praise be to God who revealed the book and did not make it crooked, praise be to God who revealed the Qur'an in the language of the Arabs as an explanation to the worlds. Praise be to God who said: (We know indeed that they say, "It is a man that teaches him." The tongue of him they wickedly point to is notably foreign, while this is Arabic, pure and clear).

We pray and salute the messenger as a mercy to the worlds and his good and pure family and good companions.

The researcher Mont Jamry Watt says in his book (Islam and Christianity Today): (I am not a Muslim in the usual sense, yet I hope to be a Muslim as a person who has surrendered to God. However, I believe that the Qur'an and other expressions of Islamic perspective contain a tremendous repertoire of divine truth, which I and other Westerners still must learn a lot from it)

The attention of researchers has aroused the issue of influence between Eastern Arab Islamic literature and Western literature, and among these influenced works is the famous work of Dante tagged with (The Divine
Comedy), which has been translated into many languages due to the effect he left on the hearts of its recipients, and studies have shown that this work - The divine Comedy influenced by Islamic works, and from here we intended to demonstrate this influence, so our research came tagged with (The Companions of Elevations Scene in a new Western Perspective), And it included a preface in which we clarified the meaning of The Companions of the Elevations in language and convention, as well as an introductory summary of the book of the Divine Comedy, while in the first topic we dealt with The Companions of Elevations in the Holy Qur'an, the commentators 'say in it, what came about it in the noble Prophet's sayings, and the affected text quoted from the book of the Divine Comedy, As for the second topic, we talked about the issue of influence, and the analysis of this influence by Islamic culture and translated texts, and we concluded our research with the most important results that we reached.

In this research we relied on the most important sources that dealt with issues of influence, as well as interpretations and linguistic and idiomatic linguistics, and in conclusion what was stated in this research right, it is 
from God, and what was in it in terms of error, it is from ourselves, "Our Lord! Condemn us not if we forget or fall into error; our Lord! Lay not on us a burden Like that which You did lay on those before us; Our Lord! Lay not on us a burden greater than we have strength to bear. Blot out our sins, and grant us forgiveness. Have mercy on us.

\section{The Linguistic Meaning of the Companions of the} Elevations

Ibn Faris said that the A ( Ain ) R ( $\mathrm{Ra}^{\prime}$ ) and F ( $\mathrm{Fa}^{\prime}$ ) letters or sounds are originally correct. Each one of them denotes the sequence of something or connected to each other, While the other indicates stillness and tranquility.

The first is the custom: the horse mane. The birds by instinct came together to a certain place which means came by following one another. The norm and its combination is a custom, which is a raised, submerged land between two plains that sprouts, as if it were the back hair of a horse ..., and the other origin is knowledge and gratitude. It says: "Someone knew so-and-so, with recognition and knowledge." This is well known. This indicates what we have said about his sojourning to him, because whoever denies something is desperate of it and forbids it.) And the two origins through which we can reach the meaning of The Companions of the Elevations mentioned in the Noble Qur'an, for it is the high place and this is the first origin mentioned by Ibn Faris, and it is also the place where those present know each other as God the Most High said: (On the heights will be men who would know every one by his marks).

Ibn Manzur said: Customs is a plural of custom, and it is every most high place.

\section{The Idiomatic Meaning of the Companions of the Elevations}

Al-Qadi al-Jarjani (816 AH) said: (Al-A'raf The heights):refer to the one who is informed and is the place of witnesses to the truth in everything, manifested by his qualities that that thing is its appearance and it is the place of supervision over the parties, God Almighty said: (On the heights will be men who would know every one by his marks), Al-Zubaidi mentioned it in his crown (1205 AH), and he said: (It is the barrier between Heaven and Hell).

Kafawi said: (Every high level among the Arabs is customary). while in the Al-Waseet dictionary:( It is the barrier between Heaven and Hell).

Through these idiomatic definitions, it becomes clear to us that there is a close connection between the language and the idiom, some people of the language see it as high, and the people of the idiom see it as that high place between Heaven and Hell, in addition to that, the people of the language added a meaning to the costumes or norms and said: It is that place in which the present know some of them It is taken from the Almighty saying: (On the heights will be men who would know every one by his marks).

\section{The Divine Comedy}

It is an epic poetry composed by Dante Alighieri between 1308 until his death in 1321 AD. The Divine Comedy is the main work of Dante and is one of the most important poetic epics and the most prominent in Italian literature. Hassan Osman's translation of it is the most important and broadest translation of Arabic for it, and many consider it to be one of the best literary works of literature at the global level.

The poetic epic contains an imaginary view with the help of metaphorical elements about the afterlife according to the Christian religion, and contains medieval philosophy as it developed in the Western Church (Roman Catholicism).

The Divine Comedy is divided into three parts: Hell, Purgatory, and Heaven. The section of Hell is the most famous in this epic, and it consists of 34 syllables or chants, while each of the other two sections consists of 33 , meaning that the Divine Comedy consists of 100 syllables or a whole hymn. The epic consists of 14,233 verses.

The saga or the epic is a fictional journey that Dante made in the Three Kingdoms, "Hell, Purgatory, and Heaven" in the afterlife, according to the events of the saga, which took a week; Two days in Hell, four in Purgatory, and one day in Heaven.

II.

\section{THE COMPANIONS OF ELEVATIONS} IN THE HOLY QURAN:

Allah says: Between them shall be a veil, and on the heights will be men who would know every one by his marks: they will call out to the Companions of the Garden, "peace on you": they will not have entered, but they will have an assurance (thereof). When their eyes shall be turned towards the Companions of the Fire, they will say: "Our Lord! send us not to the company of the wrongdoers." The men on the heights will call to certain men whom they will know from their marks, saying: "Of what profit to you were your hoards and your arrogant ways? "Behold! are these not the men whom you swore that Allah with His Mercy would never bless? Enter ye the Garden: no fear shall be on you, nor shall ye grieve." The Companions of the Fire will call to the Companions of the Garden: "Pour down to us water or anything that Allah doth provide for your sustenance." They will say: "Both these things hath Allah forbidden to those who rejected Him." 
The Companions of Elevations According to the Commentators Abu Jaafar said: As for Allah saying: (On the heights will be men), The "al-A'raf" the costume is a plural, one of which is "Arif," (Knowledgeable) and every hill from the ground according to the Arabs is "Arif" (high ground). Rather, it was said that the rooster is known by "aurf", (Crest) because of its height over what other than his body, and among them is the verse of Shamakh bin Dirar:

\section{And they kept exaggerating conventions,}

as if they were a spear towards it and towards the wind as

$$
\text { a center }
$$

Al-Sadi used to say: It is called "al-A'raf", because his companions know people. On the authority of Ibn Abbas: "Al-A'raf" is the honorable thing. And from him also: "AlArif," a wall like the crest of a rooster.

Al-Shaabi said: Abd al-Hamid bin Abd al-Rahman sent to me, and with him Abu Al-Zinad Abdullah bin Dhakwan, the lord of Quraysh, and if they were among The Companions of Elevations, a male not as mentioned, then I told them: If you wish, I told you of what Hudhaifa mentioned, then they said: Give! I said: Hudhayfah mentioned The Companions of Elevations, so he said: They are people by whom the good deeds of Hell have exceeded, and their bad deeds fall short of Paradise. If their eyes were turned away from the owners of the fire, they said "Our Lord! send us not to the company of the wrong-doers." They have been shown like that Your Lord, Blessed and Exalted looked to them and said: Go and enter Heaven, for I have forgiven you.

Al Shabi's statement is close to what Dante mentioned, as will come later.

According to Ibn Katheer's commentary that when the Almighty mentioned addressing the people of Paradise with the people of Hell, He warned that between Heaven and Hell there is a veil, which is the barrier that prevents the people of Hell from reaching Paradise. One, which is that they are people whose good and bad are equal. It was stated by Hudhayfah, Ibn Abbas, Ibn Masoud, and other than one of the predecessors and successors, may God have mercy on them.

In Tafsir al-Tahrir and al-Tanweer by Ibn Ashur: Definition in Allah saying " The Companions of the Elevations" The covenant has evidence mentioned above in His saying: "On the heights will be men." And the evidence of His saying here " whom they will know " ; Since it is not correct for those men to be called by all those who were according to The Companions of Elevations, nor to be known by their names all who were on the norms, despite the different ages and nations, what is meant by the people of the Elevations are the men who were mentioned in the previous verse by His saying: "On the heights will be men." As if it was said: And those men who follow customs or high ground called men. And the expression of them here in the adherents of customs high ground is a manifestation of the place of verbosity, since it was apparently necessary to say: and they are called men, but when the previous verse was multiplied in what is suitable for the return of consciences to it, the manifestation took place in the place of pronouns, in order to ward off confusion.

After that, Ibn Ashur continues to clarify these indications, stating that the call signals the dimension of the addressee, and it appears that the people of Elevations when they looked with their eyes to the fire knew men, or before that when they were passed by the people of hell, they knew men who were mighty in the world. Especially here, what is meant should be the self-diagnostics that characterize people, not the particular characteristic of all the people of hell, as it is in the previous verse.

So what is meant by this verse is to mention something about the matter of the Hereafter, in which there is a warning and an exhortation to the mighty polytheists among the Arabs who used to despise the weak of the believers, and among them are slaves and poor. And that is by way of imposition; That is, if they assumed the sincerity of the existence of Paradise, then these are not people to dwell in Paradise because they would not believe in Paradise, and their intention from this is to deny the Prophet, may God bless him and grant him peace, and to show what they consider wrong from his sayings, and this is like their saying:" The Unbelievers say (in ridicule): "Shall we point out to you a man that will tell you, when ye are all scattered to pieces in disintegration, that ye shall (then be raised) in a New Creation? ." So they made the tearing and annihilation of bodies a sign of the nullification of the gathering, and they were silent about the cramming of bodies that were not torn. And all of this is from misunderstanding, poor awareness, and confusion between norms and mentalities.

Ibn al-Kalbi said: He calls the people of elevations while they are on the wall, O Walid bin al-Mughira, O Abu Jahl ibn Hisham, and so-and-so, for these are the men whom they know with their features, and they were among the people of honor and pride.

The Quran verse "Behold! are these not the men whom you swore that Allah with His Mercy would never bless?" From the words of the companions of elevations. The interrogation in His saying, "Those who swore," is used in the report 
The reference to (these) to a people from the people of Paradise who were weak in this world and despised by the polytheists with the evidence of his saying: \{who you swear will not receive God mercy\} and his saying: "Enter Paradise." These commentators said such as Salman, Bilal, Khubab, and Suhaib are among the weak of the believers, either That they had settled in Paradise at that time God glorified them to the people of elevations and the men who addressed them, or that dialogue took place before they were admitted to Paradise. And he swore them to them to show their stiffness in their belief and that they do not have any doubts about that, as the Almighty said: " They swear their strongest oaths by Allah, that Allah will not raise up those who die" and His saying".. Allah with His Mercy would never bless?".

He is the one who is sworn to, and they have highlighted the negation in their speech of observing the negation of the words of the Messenger, may the prayers and peace be upon him, or the believers, and that is that the gospels of the Qur'an are for those weak, and his promise to them of paradise, and his praise for them was given the status of words that say: God attains them with mercy. That is, that Allah's sheltering them in the abode of His mercy, that is, Paradise, is made the same as the Nile, which is the occurrence of the beloved matter sought for, as mentioned earlier in His saying: " their portion appointed must reach them from the Book (of decrees)". Above, the shelter was called the verb "to receive" as a metaphor, and mercy was made like a machine for getting, as it is said: He obtained the fruit in a tool, then the $\mathrm{B}\left(\mathrm{Ba}^{\prime}\right)$ letter was for the machine, or mercy is made as a dress for getting, so the $\mathrm{B}$ $\left(\mathrm{Ba}^{\prime}\right)$ is for clothing. And the obtaining here is a metaphor, and they deliberately used this appreciated speech and denied it and said: ".. Allah with His Mercy would never bless?".

This system, whose oath was narrated, heralds their mockery of the weakness of the believers in the world, and the commentators neglected the interpretation of this verse according to its systems.

And the verse: "Enter Paradise." It was said that a saying that is omitted is an abbreviation of the meaning of the context on it, and the saying about it is omitted a lot, especially if the saying is a constructive sentence. Appreciation: God said to them, "Enter Paradise". The matter is in his saying: "Enter Paradise" for supplication, because those referred to by these are people from the people of Paradise, because at that time the people of Heaven have settled in Heaven and the people of Hell in Hell, as the previous verses require of his saying:" they will call out to the Companions of the Garden, "peace on you": they will not have entered, but they will have an assurance (thereof)." Therefore, it is necessary to make the matter for supplication.

\section{The Companions of Elevations in the Sayings of the Prophet}

Al-Bayhaqi, may God have mercy on him, said: We narrated on the authority of Ibn Abbas that he said customs are the honorable thing, and we narrated on the authority of Hudhaifa ibn al-Yaman that he said: The owners of customs are people whose good deeds have been exceeded by Hellfire and their bad deeds have been reduced to Heaven. So, while they are like that, when your Lord came to them and said to them: Get up and enter Paradise, for I have forgiven you.

This was narrated with its meaning and in the hadith of Ali bin Abi Talha on the authority of Ibn Abbas in His saying: " Between them shall be a veil, and on the heights will be men who would know every one by his marks ".

He said: They know the people of Hell with black faces and the people of Paradise with white faces. He said: The customs are the wall between Heaven and Hell, and he said: " They did not enter it while they covet". They sought to enter it, and if they look at the fire, seek refuge in God from it, and God will admit them to Heaven.He Said "Behold! are these not the men whom you swore that Allah with His Mercy would never bless?". This means the companions of elevations: " Enter ye the Garden: no fear shall be on you, nor shall ye grieve."

\subsection{The Concept of the Companions of the Elevations in Comedy According to Dante}

I said with horror in my head: My teacher, what is this that I hear? And who are these people who seem so overcome by pain?

He replied: This miserable image is taken by unfortunate souls for those who lived without shame or praise.

They were mixed with that evil bunch of angels, who were neither rebellious nor loyal to God, but were for themselves.

Heaven expelled them so that their beauty would not diminish; Do not accept them in deep hell, so that sinners will not gain some pride on them.

I said: My teacher! Any bitter pain that makes them cry violently? He answered me: I will tell you this very briefly. These people have no hope of death, and their blind life is very wasteful, as they envy all other destinies. The world does not remember them, and mercy and justice despise them: Let us mention them, but look and go. It is possible to note from the texts mentioned above, the clear influence of the Qur'an texts upon Dante. 
For example: Heaven expelled them so that their beauty would not diminish; They are not accepted by deep Hell.

It has been quoted from the Almighty saying:" they will call out to the Companions of the Garden, "peace on you": they will not have entered, but they will have an assurance (thereof). When their eyes shall be turned towards the Companions of the Fire, they will say: "Our Lord! send us not to the company of the wrong-doers."

He expressed the owners of Paradise as in the sky, and the owners of Hell expressed as in deep hell. To quote another version of Dante's songs, he said: So that the sinners do not gain some pride on them. It has been quoted from the Almighty saying: "Behold! are these not the men whom you swore that Allah with His Mercy would never bless?" So the response came from Allah " Enter ye the Garden: no fear shall be on you, nor shall ye grieve."

It is better to move to the images quoted from the Prophet's Sunnah, for his saying: This miserable image is taken by unfortunate souls of those who lived without shame or praise. They were mixed with that evil clique, who were neither rebellious nor loyal to God, but were for themselves.

It has also been quoted from the saying of the Prophet, may God's prayers and peace be upon him: (The owners of customs are people whose good deeds exceeded the fire, and their sins exceeded them from heaven).

His saying: "to those who lived" wanted by those who have traditions, and he wanted praise for those whose good deeds exceeded the Hellfire, and he wanted to shame those with whom their sins were limited to Paradise. From here we can see the extent to which Western works have been influenced by Islamic culture and rhetorical images.

\section{AL-ARAF (ISLAMIC LIMBO) IN THE DIVINE COMEDY}

The attention of researchers has aroused the issue of influence and interaction between the eastern Arab Islamic literature and the Western literature, and among these influenced works is the famous work of Dante, tagged with (The Divine Comedy), which has been translated into many languages due to the impact it left on the hearts of its recipients, and studies have shown that this work - comedy The Divine - influenced by Islamic works, many studies have referred to the translation of Islamic texts into foreign languages, and among these texts is the story of Isra and Mi'raj mentioned in the Holy Qur'an and the Sunnah of the Prophet, among the events of Isra 'and Mi'raj, there was the incident of the Messenger of God Muhammad (peace and blessings be upon him) seeing hell and seeing those tormented in it and asking him about them and their condition. Gabriel, peace be upon him, was responding to the questions of the Prophet Muhammad, may God bless him and grant him peace. In Surat Al-A'raf that we mentioned at the beginning of this paper. Miguel Asen says: the first areas of the underworld that Dante visited were one that was set aside for souls whose owners did not do good nor did they harm. Dante called this place "limbo".

The term limbo is the same as the term al-araf, except that Dante referred to the term familiar to his Catholic doctrine. (Limbo _ The Costumes Al-Araf).

\section{The References of the International Encyclopedia}

Al-A'raf is a Quranic term that is interpreted as a veil or barrier between Heaven and Hell, preventing the people of Hell from reaching Paradise. The limbus in Roman Catholic theology is the home of spirits who do not enter Heaven or Hell. And the Latin word derived from it means border. The souls in this middle country enjoy complete natural happiness - according to the Christians - but they lack the spiritual pleasure that comes from seeing God.

Roman Catholic theologians have developed two concepts of Limbos, one of which is the Fathers' Limbos, which is the transitional home or the state of the souls of the benevolent who died before the mission of Christ. Many Christians believe that Jesus, the son of Mary, peace be upon him, took those souls with him to heaven after he was resurrected from his death.

The other is the subject of children's limbo which is the eternal place or the case of children who died without being baptized. The idea of the children's limbo is based on the belief that baptism is a condition for entering Heaven. However, unbaptized children have not committed a sin, and therefore they do not deserve the torment of Hellfire.

The infant limbos is part of the teachings of many Roman Catholic theologians, but it is not part of the official doctrine of the Church.

Miguel referred to the use of the book of antiquity; As Virgil, Ovid, and Statius, Latin name (limbos); Meaning the fringes (fringe) or "zig" or the letter that adorns the lower part of the garment, which in any case is a name whose origin is ambiguous. As for the name used by the Bible and the clergy for the house in which spirits who did not sin or do good go out, it is (Abraham's bosom) not (limbo) at all.

It is not really known who introduced this use in Christian literature, as it suddenly appeared in the works of the exegetes who dealt with the works of Peter Lombard, who are contemporaries of Dante, who gave this name to the 
abode of unbaptized children, and the fathers mentioned in the Old Testament.

Dante placed this house directly above the fire, as if it were attached to it, and divided it into two parts: the section adjacent to Hell, which is intended for those who did not sin and did not do good, and to the angels who remained neutral during the devil's disobedience to God. The other section is the original limbo, which is a deep shaded valley, in the middle of which there is a palace surrounded by seven walls, with seven gates leading to a beautiful meadow.

The limbo inhabited the children who died innocent, but were not baptized, and the men and women who lived a righteous life, but they were either pre-Christian pagans, and Muslims but famous poets, moralists, philosophers, or heroes.

As for the suffering to which these people are subjected, it is purely moral, caused by their longing to see God. When they were deprived of the blessings of Paradise and exempt from corporal punishment, they were suspended between Heaven and Hell, and this middle state provided them with a special opportunity that enabled them to learn about the affairs of both those who are soft in Paradise and those who perish in Hell.

Thus Virgil was in direct contact with Beatrici from the Limbo, and he was leading Dante through Hell and Purgatory, and called him the Inmates of Fire and Demons, whom it seems clear that he knows their faces well.

The truth is that the absence of precedents in the Bible and almost all theological writings of the image that Dante placed in his poem is something that we should not discuss for long That is because the name and description of the place, that description rich in details, and the classification of its inhabitants, so that they were made pagans or even Muslims, in addition to the details of their lives and their conditions, are all matters for which we cannot find adequate justification in the Catholic doctrine, which has reservations a lot regarding these matters and other affairs The other life and its resurrection and reckoning.

As for Islam, its position was completely different. This is because the absence of anyone or an infallible authority in Islam imposes on the believers the boundaries between the beliefs of religion and freedom of thought, was the reason for the entry of a large number of myths and legends on Islamic concepts, especially Judaism, Mazdiyya and Eastern Christianity, the proportions of those who introduced them to the Prophet and his companions, even They give it the characteristic of legitimacy that almost affects the Qur'an.
This paper may provide us with a key that explains the mysteries that reveal Limbo of Dante, a subject that Christian theology left unresolved.

The Qur'an refers to a house from the role of the other world which it called (Al-A'raf) located between the homes of hostility and the homes of the wretched, so norms are a wall between heaven and hell. The customs are a plural of crest, which is every raised from the ground, and from it. It was said: The rooster's crest, because of its height over other parts of the body, was called that. Because of its height, I know and see what has fallen.

We see that the meaning of the word is similar to the word limbos, but the word limbo did not take the meaning of a house from houses until the thirteenth century AD, the Arabic word took this meaning, in addition to its original meanings since the era of the Prophet Muhammad, peace and blessings be upon him.

Islamic stories developed different descriptions of customs, as I once mentioned it as a beautiful valley strewn with fruit trees, or as a valley located behind a high mountain, or after it a great round wall, or just a hill or a mountain. If these descriptions are collected together, we will come out with a picture not much different from the image that Dante painted for Limbo, especially if we complete the picture with the description that was repeated in the story of the Mi'raj of Abraham's Paradise - peace be upon him - and the entrance to Hell, which resembles that palace which is the adjacent section of Hell in Dante's limbo. Seven gates and seven walls.

The truth is that this palace, for which Dante made seven walls and seven gates, is almost a mirror image of the Islamic palace in Heaven, surrounded by eight walls, and has eight gates.

Here he waves to us as if Dante, by mixing the Islamic design of paradise and fire together, aims to symbolize the neutral nature of the souls who live in the limbo.

Islamic scholars, including Al-Ghazali himself, show that customs ( Al Araf )are the home of those who were neither pious nor corrupt, and Muslim commentators have classified it based on this theory, the sects that will enter customs ( The high land ) as follows: martyrs of jihad for the sake of God who were deprived of paradise for their disobedience to their fathers, and the scholars who abolished Their vanity, their virtues for which they were entitled to enter Heaven, the children of Muslims and the infidels, and finally the elves who believed in the message of Muhammad - may God bless him and grant him peace and there is no doubt that these sects clearly coincide with the sects that Dante placed in the Limbo, and they are the children who were not baptized, heroes and poets and the 
philosophers whose faith annihilated the virtues they possessed.

As for the only torment that the companions of customs ( Al Araf ), as stated in the Qur'an, and agreed upon by the commentators, it is limited to their longing for Paradise: "And they did not enter it while they covet." These are the ones whose good deeds are equal to their sins. They are suspended between Heaven and Hell, and when they are in this situation, they can look at the happy in Heaven or the wretched in Hell, and talk to them.

\section{CONCLUSION}

It has been concluded after this interesting trip that we spent with the place of al-A'araf or Limbo as it is with Dante, we reach the most important results that we have reached through our research.

The issue of influence between cultures cannot be denied as it is agreed upon, and from this way, the influence of Western literature with Islamic culture, and we have explained this and explained it in the lines of our discussion through the noble verses, the Sunnah of the Prophet and the sayings of the commentators.

The writer "Dante" tried to change many terminologies by relying on his culture as well as his Catholic Christian religion. Nevertheless, he could not escape in many situations, as the Islamic culture made him inclined to it and use its terminology, especially in his depiction of the image of customs ( Limbo ) ( Al Araf ).

In this paper, the discussion revolved around a major issue, which is a statement of the areas of influence that affected this literary work, so this influence was evident and we showed it to the honorable reader, so the simple statement in it was sufficient and the effect was clearly visible smoothly and simply.

In the conclusion of this paper, we cannot help but say that researchers must delve into the explanation of this issue to show the value of the Arab and Islamic civilization, which has been forgotten and forgotten for a short while ago.

\section{BIBLIOGRAPHY}

1. Surah An-Nahl: 103.

2. Islam and Christianity in the Contemporary World: 215.

3. Language standards: 4/281, Article: (custom).

4. Surat Al-A'raf: 46, part of a verse.

5. Lisan Al-Arab: 9/236.

6. Definitions: 47.

7. Crown of the Bride 24/143.
8. Colleges: 203.

9. The Intermediate Dictionary: 2/595.

10. Wikipedia, the site was visited: $12 / 14 / 2018$.

11. Ibid.

12. Surat Al-A'raf: 46-51.

13. Tafseer al-Tabari: 12/450.

14. The Diwan of Shamakh bin Dirar: 201, and in it: It remained in Yifa'.

15. Tafseer Al-Tabari 12/451.

16. Ibid.

17. The interpretation of Ibn Katheer: 3/418.

18. Tafsir al-Tahrir and Enlightenment: 8/144.

19. Surah Saba: 7.

20. Tafsir al-Tahrir and Enlightenment: 8/145.

21. Ibid.

22. Surah An-Nahl: 38.

23. Al-Tahrir and Enlightenment: 8/145.

24. Al-Tahrir and Enlightenment: 8/147.

25. The People of Faith: 1/344.

26. The Divine Comedy, Hell chapter: 103, Song 3: 31-34.

27. Ibid.

28. The Divine Comedy, Hell chapter: 103, Song 3: 31-34.

29. The effect of Islam looks at the divine comedy: 90, and the effect of Islamic culture on comedy 109.

30. The International Arab Encyclopedia: 55, chapter of Hamza.

31. Ibid.

32. The Impact of Islam looks at the Divine Comedy: 9091.

33. Ibid.

34. The effect of Islam looks at the Divine Comedy: 92.

35. The influence of Islamic culture on comedy: 110.

36. Surat Al-A'raf: 46.

37. The Impact of Islam Sees the Divine Comedy: 92.

\section{REFERENCES}

[1] The Holy Quran .

[2] The Impact of Islam on the Divine Comedy, Miguel Asen, translated by: Jalal Mazhar, Al-Khanji Library, Cairo, 1980.

[3] Islam and Christianity in the Contemporary World, and Watt Muntjimri, translated by: Dr. Abd al-Rahman Abdullah al-Sheikh, Egyptian General Book Authority, 1998. 
[4] The influence of Islamic culture on Dante's divine comedy, Salah Fadl, Dar Al-Shorouk, Cairo, 3rd Edition, 1986.

[5] Crown of the Bride, one of the jewels of the dictionary, Muhammad bin Muhammad bin Abdul Razzaq al-Husayni, Abu al-Faid, nicknamed Murtada, al-Zubaidi, (1205 AH), verified by a group of investigators, Dar al-Hidaya.

[6] Liberation and Enlightenment, Muhammad Al-Taher Ibn Ashour Al-Tunisi (1393 AH), Al-Dar Al-Tunisi - Tunis, 1984.

[7] Definitions, Ali bin Muhammad bin Ali al-Zain al-Sharif al-Jarjani (816 AH), under: Ibrahim al-Ibyari, Arab Book House - Beirut, I / 1, 1405 AH.

[8] Interpretation of the Great Qur'an, Abu al-Fida Ismail bin Omar bin Kathir al-Qurashi al-Dimashqi (774 AH), under: Mahmoud Hassan, Dar al-Fikr, 1414 - 1994.

[9] Jami al-Bayan in the interpretation of the Qur'an known as Tafsir al-Tabari, Muhammad bin Jarir bin Yazid bin Katheer bin Ghaleb al-Amili, Abu Jaafar al-Tabari, (310 $\mathrm{AH})$, under: Ahmad Muhammad Shaker, Foundation for the Resala, I / 1, 1420 - 2000 .

[10] The Diwan of Shammakh bin Dirar Al-Dhabyani, translated by Salah Al-Din Al-Hadi, Dar Al-Maarif, Egypt, 2001.

[11] The People of Faith, Ahmed bin Al Hussein bin Ali bin Musa Abu Bakr Al-Bayhaqi (458).

[12] Colleges, Abu Al-Takha 'Ayoub bin Musa Al-Husseini AlKafoumi (1094 AH), under: Adnan Darwish - Muhammad Al-Masry, Al-Risala Foundation - Beirut, 1419 - 1998.

[13] The Divine Comedy, Chapter of Hell, by Dante Aljieri, translated by: Hassan Othman, Dar Al Maarif, Cairo, 3rd Edition, 1988.

[14] Lisan al-Arab, Muhammad bin Makram bin Manzoor alAfriqi al-Masri (711 AH), under: Abd al-Salam Muhammad Harun, Dar al-Fikr, 1399 - 1979.

[15] Al-Waseet Lexicon, Ibrahim Mustafa-Ahmad Al-ZayatHamid Abdel-Qader-Muhammad Al-Najjar, U: Academy of the Arabic Language, Dar Al-Da`wah, Cairo, 2001.

[16] Standards of Language, Abu Al-Hussain Ahmad Ibn Faris Ibn Zakaria (395 AH), translated by: Abd al-Salam Muhammad Harun, Dar al-Fikr, 1399 - 1979.

[17] The Global Arab Encyclopedia, the global circle of knowledge, more than a thousand scholars, authors, translators, editors, scientific references, linguists, artistic directors, consultants and institutions participated in its implementation from all Arab countries.

[18] Wikipedia, the free online encyclopedia. 